\title{
Being a patient: a medical student's perspective
}

This article was published in the following Dove Press journal:

Advances in Medical Education and Practice

15 February 2017

Number of times this article has been viewed

\author{
Dara Rasasingam' \\ Georgina Kerry² \\ Shyam Gokani' \\ Alexander Zargaran ${ }^{3}$ \\ Javier Ash' \\ Aaina Mittal' \\ 'Department of Medicine, Imperial \\ College School of Medicine, \\ Imperial College London, London, \\ ${ }^{2}$ Department of Medicine, University \\ of Birmingham Medical School, \\ Birmingham, ${ }^{3}$ Department of Medicine, \\ St. George's, University of London, \\ London, UK
}

\begin{abstract}
Medical education follows the clinical drive toward patient-centered care and, therefore, puts strong emphasis on the development of empathy by medical students. It has, however, been found that there is a decline in empathy throughout a student's education. Students' participation in role-play as the doctor has been proved to improve patient care in a clinical capacity. Here, it is proposed that patient role-play can enhance patient care holistically, by enhancing key communication skills and student's empathy.
\end{abstract}

Keywords: empathy, role-play, medical education

\section{Being a patient: a medical student's perspective}

Empathy and maintenance of the patient at the center of the care process have been shown to decline as a student progresses through their medical education. This occurs despite a strong focus on the teaching of communication skills by medical schools and the ubiquitous reinforcement of patient-centered care in the current health care system. ${ }^{1,2}$ The reasons for which this decrease in empathy exists are several, including poor work-life balance and a low sense of well-being. In solving the decrease in empathy by medical students, these elements must be investigated pragmatically and each offered an appropriate solution, for example, by practicing mindfulness and stress-reducing techniques. ${ }^{3}$ However, that is beyond the scope of this article, which focuses on generic mechanisms of developing empathy in medical students regardless of the underlying cause of decline.

Simulated patient/doctor role-play has been demonstrated to improve patient care, by developing student knowledge of medical conditions and communication skills, with which comes an element of improved empathy. ${ }^{4}$ It is known that where students take on the role of the doctor benefits accrue not only in gaining knowledge, but also in developing an understanding of the role of the doctor and the significance of building up rapport with patients. ${ }^{5}$ Here, we propose that a valuable learning opportunity is presented in the student taking on the role of the patient as well as the doctor. Current literature regarding the student as the patient is promising in supporting development of empathy, and further emphasis is required to promote the formal inclusion of patient role-play in the medical curriculum. ${ }^{6}$

Empathy is the ability to identify and understand another person's emotional state. ${ }^{7}$ While students may understand the importance of empathy, there is currently no consensus on the appropriate method for teaching this quality. ${ }^{8}$ McKee categorizes emotional intelligence into five domains, ${ }^{9}$ with empathy being suggested as the most
Correspondence: Dara Rasasingam Department of Medicine, Sir Alexander Fleming Building, Exhibition Road, South Kensington Campus, Imperial College, London SW7 2AZ, UK Email dsrI 12@imperial.ac.uk 
difficult of those domains to develop. ${ }^{10}$ Those students who have had higher level formal training in the development of empathy are able to attend the patient holistically, rather than on a purely medical basis. ${ }^{11}$ Therefore, it derives that should all medical students receive appropriate formal training in empathy, all will provide appropriate holistic patient care.

Tomorrow's Doctors require that a doctor must reflect on their actions. ${ }^{12}$ Peer feedback is a critical part of learning and reflection and a critical dimension of a medical student's development. Where students make up both parties in the patient-doctor scenario, they can analyze various communication techniques and styles demonstrated by peers. Personal experience, both in delivering and receiving empathetic statements made by fellow students, potentiates the understanding of how best to provide quality care and enhance patient satisfaction. ${ }^{13}$

Support for the inclusion of this form of simulation is evident in educational theory. Role-play engages Kolb and Fry's four domains of "learning environments". ${ }^{14}$ These include allowing a student to experience a diverse array of communication styles; reflect on their effectiveness; and subsequently incorporate that into future practice. ${ }^{15}$ Furthermore, student engagement provides active learning and can be used to deliver clinical content from the curriculum. ${ }^{13}$ In this manner, the student not only gains core clinical competencies but also enhances their own medical knowledge, combining key elements of clinical presentations with those situations where empathy is vital.

Although students do play the patient in some medical schools, this is not the case in all UK medical schools. Often, students role-play the patient during informal revision or teaching times, rather than as part of the core communication skills sections of the curriculum. Teachers associated with the University of Birmingham Medical School suggest that students practice history taking and patient examination as peer groups and often students volunteer as the patient during group sessions. However, during formal communication skills teaching, external actors and patient volunteers play the patient role, and students take on the role of themselves or the health care professional.

The student as the patient in role-play has similar effectiveness to simulated-patient role-play. ${ }^{16}$ Yet, there are additional benefits to incorporating students as the patient. Simulated patients generally necessitate financial expenditure, whereas medical students do not, therefore saving on resources. ${ }^{6,17}$ Additionally, the student develops transferrable skills such as providing feedback which is useful in peer study sessions and in teaching, a compulsory part of the doctor's working life.

Role-play is a well-known phenomenon to medical students, and the participation in both sides of the doctor-patient partnership is not alien to them. However, personal experience notes that considerably more emphasis is placed upon the student as the doctor, rather than the patient. Although this is sensible considering the student is working toward becoming a doctor, for the student to provide holistic patient care they must possess empathy. While no two medical students are the same, the completion of the degree and the ability to competently undertake a career in the profession necessitate certain personality attributes. Quantitative research into the value in students taking on the role of the patient is limited, but current literature and personal experience are positive and an alteration in the formal medical curriculum to include the student playing the role of the patient can result in an improved caliber of doctor graduating from UK medical schools.

\section{Disclosure}

The authors report no conflicts of interest in this work.

\section{References}

1. Bombeke K, Symons L, Debaene L, De Winter B, Schol S, Van Royen P. Help, I'm losing patient-centredness! Experiences of medical students and their teachers. Med Educ. 2010;44(7):662-673

2. Hojat M, Mangione S, Nasca TJ, et al. An empirical study of decline in empathy in medical school. Med Educ. 2004;38(9):934-941.

3. Neumann M, Edelhäuser F, Tauschel D, et al. Empathy decline and its reasons: a systematic review of studies with medical students and residents. Acad Med. 2011;86(8):996-1009.

4. McIlvried DE, Prucka SK, Herbst M, Barger C, Robin NH. The use of role-play to enhance medical student understanding of genetic counseling. Genet Med. 2008;10(10):739-744.

5. Wagner PJ, Lentz L, Heslop SD. Teaching communication skills: a skills-based approach. Acad Med. 2002;77(11):1164.

6. Bosse HM, Schultz JH, Nickel M, et al. The effect of using standardized patients or peer role play on ratings of undergraduate communication training: a randomized controlled trial. Patient Educ Couns. 2012;87(3): 300-306.

7. Smajdor A, Stöckl A, Salter C. The limits of empathy: problems in medical education and practice. J Med Ethics. 2011;37(6):380-383.

8. Hirsch EM. The role of empathy in medicine: a medical student's perspective. Virtual Mentor. 2007;9(6):423-427.

9. Goleman D. Emotional intelligence: why it can matter more than $I Q$. New York: Bantam Books.; 1995:43-44.

10. McKee A. How to help someone develop emotional intelligence [Internet]. 2015. Available from: https://hbr.org/2015/04/how-tohelp-someone-develop-emotional-intelligence. Accessed August 29, 2016.

11. Fine VK, Therrien ME. Empathy in the doctor-patient relationship: skill training for medical students. J Med Educ. 1977;52(9):752-757.

12. General Medical Council. Tomorrow's Doctors Outcomes and standards for undergraduate medical education. 2009. Available from: http://www. gmc-uk.org/Tomorrow_s_Doctors_1214.pdf_48905759.pdf. Accessed November 20, 2016. 
13. Manzoor I, Mukhtar F, Hashmi NR. Medical students' perspective about role-plays as a teaching strategy in community medicine. $J$ Coll Physicians Surg Pak. 2012;22(4):222-225.

14. Kolb D, Fry R. Toward an applied theory of experiential learning. In: Cooper C, editor. Theories of group processes. 1975;33-57.

15. Nestel D, Tierney T. Role-play for medical students learning about communication: guidelines for maximising benefits. BMC Med Educ. $2007 ; 7: 3$.
16. Mounsey AL, Bovbjerg V, White L, Gazewood J. Do students develop better motivational interviewing skills through role-play with standardised patients or with student colleagues? Med Educ. 2006;40(8): 775-780.

17. Bosse HM, Nickel M, Huwendiek S, Jünger J, Schultz JH, Nikendei C. Peer role-play and standardised patients in communication training: a comparative study on the student perspective on acceptability, realism, and perceived effect. BMC Med Educ. 2010;10:27.

\section{Publish your work in this journal}

Advances in Medical Education and Practice is an international, peerreviewed, open access journal that aims to present and publish research on Medical Education covering medical, dental, nursing and allied health care professional education. The journal covers undergraduate education, postgraduate training and continuing medical education including emerging trends and innovative models linking education, research, and health care services. The manuscript management system is completely online and includes a very quick and fair peer-review system. Visit http://www.dovepress.com/testimonials.php to read real quotes from published authors.

Submit your manuscript here: http://www.dovepress.com/advances-in-medical-education-and-practice-journal 